\title{
Pengaruh Work Overload dan Perceived Organizational Support dengan Job Stress Pegawai Bank di Masa Pandemi
}

\author{
ADINDA REZA MAULINA \& DIMAS ARYO WICAKSONO* \\ Fakultas Psikologi Universitas Airlangga
}

\begin{abstract}
ABSTRAK
Stres kerja merupakan permasalahan umum yang diterima pegawai, tetapi bagaimana stres kerja pegawai yang sekarang dihadapkan dengan kondisi pandemi COVID-19 terutama pegawai pada bidang ekonomi seperti Bank. Penelitian ini bertujuan untuk mengetahui apakah terdapat pengaruh work overload dan perceived organizational support dengan job stress di masa pandemi pada pegawai Bank di Surabaya. Pada penelitian ini sebanyak 93 partisipan. Instrumen penelitian yang digunakan job demand oleh Bakker. Perceived organizational support oleh Eisenberger. Sedangkan job stress miliki Cullen. Analisis data menggunakan regresi linear dan multiple regresi dengan aplikasi Jamovi. Hasil penelitian ini menunjukan bahwa work overlaod memiliki pengaruh positif yang signifikan dengan job stress sebesar 18,4\%. Sedangkan perceived organizational support memiliki pengaruh yang negatif tidak signifikan dengan job stress overlap 2,04\%. Selanjutnya work overload dan perceived organizational support dengan job stress yang didapatkan hasilnya adalah signifikan dengan overlap sebesar $21 \%$.
\end{abstract}

Kata kunci: job stress, pandemi COVID-19, perceived organizational support, work overload,

\begin{abstract}
Job stress is a common problem for employees, but how is the job stress of employees being accepted with the COVID-19 pandemic conditions, especially employees in the economic sector such as banks. This study to determine there is the influence of excessive work and perceived organizational support with job stress during the pandemic on Bank employees in Surabaya. The study was joined by 93 participants. The research instrument used was the job demand by Bakker. The organizational support felt by Eisenberger. Job stress by Cullen. Data analysis using linear regression and multiple regression with the Jamovi application. The results of this study indicate employees have a significant positive effect with job stress by $18.4 \%$. Organizational support which is felt to have a negative and insignificant effect with work stress is $2.04 \%$ overlap. Furthermore, the work overload and perceived organizational support with work stress are significant with an overlap of $21 \%$.
\end{abstract}

Keywords: job stress, pandemic COVID-19, perceived organizational support, work overload

Buletin Penelitian Psikologi dan Kesehatan Mental (BRPKM), 2021, Vol.1 (1), 797-809

*Alamat korespondensi: Fakultas Psikologi Universitas Airlangga, Kampus B Universitas Airlangga Jalan Airlangga 4-6 Surabaya 60286. Surel: aryo.wicaksono@psikologi.unair.ac.id

Naskah ini merupakan naskah dengan akses terbuka dibawah ketentuan the Creative Common Attribution License (CC-BY-4.0) (http://creativecommons.org/licenses/by/4.0), sehingga penggunaan, distribusi, reproduksi dalam media apapun atas artikel ini tidak dibatasi, selama sumber aslinya disitir dengan baik. 


\section{P E N D A H U L U A N}

Bank memiliki peran yang sangat penting untuk negara yang berguna untuk pembangunan nasional. Menurut undang-undang No. 10 Tahun 1998 tentang definisi bank umum yaitu sebagai badan usaha yang menghimpun dana dari masyarakat dalam bentuk simpanan dan menyalurkan kepada masyarakat dalam bentuk kredit atau bentuk lainnya untuk meningkatkan taraf kehidupan banyak orang (UURI, 1998). Pegawai bank memiliki tugas dan target yang perlu dicapai untuk mencapai tujuan yang ditentukan perusahaan, namun hal tersebut tidaklah mudah dengan adanya novel corona virus.

Pada masa pandemi yang dikarenakan Covid-19 di Indonesia telah menimbulkan dampak yang sangat besar terhadap perekonomian. Pandemi telah memberi dampak signifikan pada sektor perbankan. Begitu penting sekali kontribusi bank untuk memulihkan ekonomi di Indonesia yang terdampak karena pandemi Covid-19 (Syahrizal Sidik, 2020). Pada masa pandemi ini memberikan dampak pada pegawai yaitu kecemasan karena terpapar virus pada lingkungan kerja, ketegangan permasalahan perusahaan yang ditimbulkan, tuntutan lingkungan yang muncul, dan perlunya adaptasi dengan perubahan yang terjadi hal tersebut menyebabkan stres kerja itu datang (Putri, 2020). Pada hasil survei PPM Manajemen $80 \%$ pegawai mengalami gejala stres selama masa pandemi Covid-19 yang dimana alasan paling banyak didapatkan karena kekhawatiran akan kesehatan mereka dan keluarga mereka. Pada hasil survei PPM juga menyebutkan sektor tertinggi yang mengalami stres kerja adalah sekot jasa sebesar 31\% (Karunia, 2020). Pada penelitian yang dilakukan Singh bahwa pekerja medis dan masyarakat lainnya mengalami masalah psikologis akibat pandemi tersebut, seperti kegelisahan, depresi, dan stres karena jumlah kasus Covid-19 dan bertambahnya tingkat kematian yang telah di konfirmasi (Singh et al., 2020). Pada survei yang dilakukan forum ekonomi dunia dan Ipsos, terdapat 13.000 pegawai di 28 negara dunia mengalami kecemasan yang meningkat karena keamanan yang dirasa kurang dan perubahan budaya organisasi mereka (Arbar, 2021).

Adapun hasil riset yang ditemukan oleh Yayasan Lembaga Konsumen Indonesia (YLKI) dalam riset keluhan konsumen terhadap jasa keuangan pada tahun 2017 dimana tingkat stres yang tinggi dapat menimbulkan persaingan yang tidak sehat untuk mencapai target yang ditentukan pada pegawai bank, khususnya yang bekerja pada bagian marketing (Setiawan, 2018). Persaingan tersebut dapat mempengaruhi mencapai tujuan perusahaan dengan berbagai cara dan dapat menyebabkan tekanan dan juga hilangnya kendali pada kinerja (Maulidyah, 2017). Selanjutnya pada International Labour Organization menyebutkan dalam studi mengenai penelitian berjudul "Health and safety in workplace for producitivity (2014) yang menjelaskan mengenai pegawai bank lebih sering mendapatkan tekanan berasal dari pekerjaan dan pada akhirnya memberikan pengaruh pada psikologi mereka yaitu stres (ILO, 2014). Pada penelitian yang dilakukan Chandra (2018) pada pegawai Bank bagian marketing yaitu KPR dimana menunjukan pengaruh negatif dan signifikan stres kerja pada kinerja pegawai (Chandra, 2018). Pada penelitian yang dilakukan Delfianti (2019) pada pegawai Bank Mandiri bagian KPR pada satu cabang saja yang menunjukan stres kerja dapat mempengaruhi kinerja mereka (Delfianti, 2019). Selanjutnya pada penelitian yang dilakukan Yuliana (2020) pada pegawai Bank perempuan pada masa pandemi dimana lingkungan kerja tidak mampu memoderasi konflik peran ganda dan stres kerja terhadap kinerja Bank (Pratiwi, 2020).

Stres kerja adalah perasaan tertekan yang dialami pegawai dalam menghadapi pekerjaan. Menurut Cullen, dkk (1985) stres kerja yaitu perasaan tidak nyaman yang dirasakan individu dapat menimbulkan kesulitan dalam menghadapi pekerjaan atau tuntutan tertentu. Pegawai yang mengalami tekanan psikologi secara emosional terkait pandemi menjadi terpukul karena lingkungan kerja mereka 
mengharuskan hidup berdampingan dengan Covid-19 (Puci dkk., 2020). Tekanan yang berasal dari lingkungan kerja, lingkungan keluarga, dan lingkungan sosial berdampak pada kecemasan. Stres juga merupakan interaksi individu dengan lingkungan, namun secara lebih terperinci stres merupakan respon yang adaptif yaitu penyesuaian diri individu karena konsekuensi tindakan, situasi, dan kejadian eksternal (lingkungan) yang menempatkan tuntutan psikologi dan fisik secara berlebihan (Luthans, 2009). Sumber dari job stress itu sendiri bisa dari individu dan organisasi yang berkaitan langsung dengan tugas, tuntutan pekerjaan, kelebihan beban kerja, konflik peran, ambiguitas peran, kecemasan pada lingkungan kerja, pengendalian yang dirasakan atas peristiwa yang muncul di lingkungan kerja (De Jonge dkk., 1999). Pada kondisi pandemi seperti ini memang dapat berpengaruh pada proses kerja pegawai seperti menurut Winarsunu (2008) kondisi kerja yang berbahaya dan tidak menyenangkan serta kontrol kerja yang rendah merupakan faktor munculnya stres kerja (Susetyo \& Ratnaningsih, 2016).

Beberapa hasil penelitian terdahulu terdapat faktor-faktor yang mempengaruhi stres kerja, seperti pada penelitian yang dilakukan Sahaduta dan Noermijati (2017) bahwa pegawai yang memiliki job stress karena beban kerja yang diberikan tinggi, sebaliknya jika job stress rendah beban kerja rendah. Pada penelitian lain, ada pegawai memiliki pengaruh yang kuat work overload dengan job stress (Rakhmawati \& Syarifah, 2017). Pada penelitian yang dilakukan Malik (2011) menyatakan bahwa kelebihan beban kerja, otoritas peran, dan kurangnya dukungan kerja memberikan kontribusi meningkatnya stres kerja. Sedangkan menurut Laschinger (2006) ketika situasi stres kerja itu muncul disitulah dukungan dari organisasi perlu untuk kebutuhan pegawai.

Beban kerja yang berlebihan, kecemasan, dan pengerjaan waktu yang diberikan hal tersebut dapat memunculkan stres kerja (Parker \& DeCotiis, 1983). Setiap orang pernah mengalami beban kerja yang terlalu berat pada suatu waktu (Gibson, Ivancevich, Donnelly, 2011). Beban kerja berlebihan adalah kondisi yang terjadi bila lingkungan memberikan tuntutan melebihi kemampuan individu. Pegawai yang merasa tertekan dengan pekerjaannya akan mengalami penurunan dalam kinerjanya tersebut (Setiawan \& Noermijati, 2018). Mayoritas pegawai yang melakukan WFH mengalami work overload pada tingkat sedang yaitu 71,2\% (Arsyad, 2021).

Beban kerja yang terlalu banyak dapat menimbulkan stres yang disebabkan keahlian yang dituntut terlalu tinggi, kecepatan kerja yang tinggi, dan volume kerja yang banyak (Alifah, 2020). Terlalu banyak pekerjaan yang diselesaikan, waktu yang terbatas untuk penyelesaian, dan kekurangan pegawai, masalah pribadi pegawai, masalah lingkungan di perusahaan yang sangat berpengaruh menimbulkan stres kerja dengan kondisi pandemi yang saat ini ada di Indonesia. Pegawai yang harusnya bisa beraktifitas dengan leluasa menjadi terbatas, disatu sisi harus menyelesaikan tugas di sisi lain harus menjaga kesehatan mereka agar tidak terkena Covid-19.Dukungan organisasi yang tersedia dan kebutuhan penting telah diakomodasi hal tersebut akan menurunkan stres kerja pegawai (Laschinger, 2006). Perceived organizational support didefinisikan sebagai persepsi pegawai atas perhatian yang diberikan oleh perusahaan untuk kesejahteraan pegawai (Eisenberger dkk., 1986). Persepsi dukungan organisasi ini mempresentasikan bagian penting dari hubungan timbal balik antara pegawai dan pemimpin atau perusahaan, karena hal tersebut mengimplikasikan apa yang telah dilakukan perusahaan bagi pegawai. Pada masa pandemi seperti ini sangat penting dukungan organisasi tidak hanya fokus pada hal yang dikerjakan pegawai dan juga pelanggan saja (Rosdiana, 2020). Terdapat survei PPM mengenai dukungan yang diharapkan pegawai ke perusahaan yaitu kebijakan bekerja dari rumah 48\%, memberikan perlindungan dari penyebaran Covid-19 43\%, kebijakan agar lingkungan kerja aman dari virus 38\%, memberikan bantuan kondisi pegawai 27\%, dan sosialisasi strategi perusahaan untuk bertahan menghadapi pandemi 25\%. (Karunia, 2020). 
Pada penelitian yang dilakukan Sudrajat dan Afrianty (2019) bahwa dukungan supervisor kepada pegawainya terhitung rendah dan tetap mempengaruhi stres kerja pegawai maka dari itu perusahaan perlu memberikan motivasi dan melakukan pendekatan pada pegawai, memahami permasalahan yang dihadapi pegawai, keluhan, dan memberikan reward bagi pegawai yang berprestasi. Perceived organizational support memiliki pengaruh yang signifikan pada kesiapan berubah karena adanya masa pandemi (Wulandari, 2021). Pada kondisi seperti ini perlunya perusahaan memberikan fasilitas kepada pegawainya dalam bekerja agar mereka merasa terlindungi dan nyaman saat bekerja seperti menurut Eisenberger, dkk (1986) dukungan organisasi juga dilihat sebagai jaminan pegawai bahwa bantuan akan tersedia dari perusahaan jika diperlukan untuk melakukan pekerjaan dan dapat mengurangi stres kerja pegawai. Memberikan fasilitas peralatan kesehatan, toleransi pencapaian kerja yang didapatkan, dan dukungan lainnya untuk pegawai dapat mengurangi stres kerja yang dimiliki pegawai. Sedangkan perusahaan yang kurang memperhatikan pegawainya atau memberikan dukungan pada pegawainya dapat berdampak pada stres pegawai seperti lingkungan kerja tidak suportif dengan menggunakan pendekatan untung-rugi saja (Siu dkk., 2008). Perubahan kondisi pada masa pandemi Covid-19 dapat mempengaruhi psikologis para pegawai yang bisa menyebabkan stres kerja serta kecemasan pegawai pada kondisi saat ini. Stres kerja dan kecemasan jika tidak diperhatikan dapat mempengaruhi tingkat gangguan kecemasan dengan konsekuensi negatif pada tubuh, mental, dan produktivitas kerja pegawai (Singh dkk., 2020). Dalam penelitian ini penulis mencoba menguji pengaruh work overload dan perceived organizational support dengan job stress pada pegawai Bank di masa pandemi karena Covid19. Telah banyak sebelumnya literatur yang meneliti tersebut, tetapi sebelum masa pandemi. Seperti penelitian yang dilakukan Chandra (2018) dan Delfianti (2019) yang dimana melakukan penelitian stres kerja pada pegawai bank sebelum masa pandemi. Penelitian yang dilakukan juga hanya pada satu cabang Bank saja dan bukan di daerah Surabaya, dan yang membuat berbeda adalah tidak dilakukan pada masa pandemi (Delfianti, 2019). Oleh karena itu, urgensi penelitian ini fokus mengetahui work overload dan perceived organizational support dengan job stress pada pegawai bank di masa pandemi. Terdapat tiga hipotesis dalam penelitian ini, yaitu (1) Terdapat pengaruh pada work overload terhadap job stress di kondisi pandemi pada pegawai Bank di Surabaya; (2) Terdapat pengaruh pada perceived organizational support terhadap job stress di kondisi pandemi pada pegawai Bank di Surabaya; (3) Terdapat pengaruh work overload dan perceived organizational support terhadap job stress di kondisi pandemi pada para pegawai Bank di Surabaya.

\section{E T O D E}

Desain PenelitianPenelitian yang digunakan adalah kuantitatif yaitu menekankan pada fenomena objektif. Penelitian ini menggunakan eksplanatori yaitu menjelaskan fenomena mengapa bisa terjadi, dengan menguraikannya, atau menguji teori yang digunakan peneliti. Penelitian ini menggunakan dengan desain cross sectional yaitu peneliti melakukan pengumpulan data hanya satu kali pada waktu tertentu dengan jawaban partisipan secara alami (Neuman, 2014). Metode yang digunakan yaitu sampling jenuh dengan memberikan alat ukur berupa kuesioner.

\section{Partisipan}

Partisipan dalam penelitian ini adalah pegawai Bank Mandiri consumer loan area Surabaya yang terdiri dari tiga cabang yaitu Niaga, Basuki Rachmat, dan Genteng Kali. Pada cabang Niaga terdapat 32 partisipan, pada cabang Basuki Rachmat terdapat 31 partisipan, sedangkan pada cabang Genteng Kali terdapat 30 partisipan. Maka, total partisipan yang didapatkan yaitu 93 partisipan. Teknik yang digunakan yaitu sampel jenuh yang mengambil seluruh anggota populasi untuk menjadi sampel partisipan penelitian. Jenis kelamin partisipan yaitu laki-laki dan perempuan, mayoritas usia partisipan 
26-30 tahun sebesar 55,6\%. Rentang masa kerja pegawai paling banyak yaitu 1-5 tahun sebesar 68,8\%. Pengambilan data diawali dengan informed consent yang menyatakan partisipan bersedia dan berpartisipasi dalam penelitian.

\section{Pengukuran}

Pengukuran yang digunakan dalam penelitian ini terdapat dua variabel independen dan satu variabel dependen. Variabel independen yang digunakan yaitu work overload dan job stress. Sedangkan variabel dependen yaitu job stress. Pengukuran yang peneliti gunakan terdiri dari tiga instrumen antara lain Questionnaire on the experience and assesment of work (QEEW) job demand questionnaire milik Bakker, dkk (2003) untuk mengukur work overload yang terdiri dari 25 aitem. Instrumen kedua yaitu perceived organizational support milik Eisenberger (1986) terdiri dari 6 aitem untuk mengukur perceived organizaitonal support partisipan. job stress scale (JSS) milik Cullen, dkk (1985) terdiri dari 6 aitem untuk mengukur stres kerja partisipan (Cullen dkk., 1985).

Ketiga alat ukur menggunakan skala likert dimana semakin tinggi skor yang didapatkan maka menunjukan dukungan yang lebih besar pada variabel tersebut. Pada Skala QEEW job demand dengan 4 pilihan jawab pada dimensi work overload terdiri dari (1="tidak Pernah", 4= "selalu") dengan koefisien reliabilitas yang didapatkan yaitu 0,773, pada dimensi emotional demand terdiri dari 5 pilihan jawaban (1= "tidak Pernah", 5="selalu") koefisien reliabilitas yang didapatkan 0,839, Pada dimensi cognitive demand terdapat 4 pilihan jawaban (1= "tidak menuntut banyak", 4="sangat menuntut banyak") koefisien reliabilitasnya 0,896. Selanjutnya pada skala perceived organizational support terdapat 7 pilihan jawaban (1= "sangat setuju sekali", 7="sangat tidak setuju sekali") dengan koefisien reliabilitas yang didapatkan 0,864. Selanjutnya pada skala Job Stress Scale terdapat 7 pilihan jawaban (1="sangat setuju sekali", 7="sangat tidak setuju sekali") dengan koefisien reliabilitas yang didapatkan 0,875. Ketiga alat ukur ini menggunakan profesional judgment dengan pihak yang ahli dalam bidang tersebut menggunakan Content Validity Index (CVI). Skor yang didapatkan dari ketiga alat ukur tersebut yaitu Job Stress Scale 0,933, Job demand questionaire 0,944, dan perceived organizational 0,902.

\section{Analisis Data}

Teknik analisis data pada penelitian ini menggunakan teknik regression linear dan multiple regresion. Sebelum melakukan regresi perlunya uji asumsi pertama yaitu uji normalitas, uji linearitas, uji multikolinearitas, analisis residual, dan deteksi outlier. Penulis dalam proses analisis dan mengolah data menggunakan prorgram Jamovi 1.2.27 for windows.

\section{HAS I L P EN EL I T I A N}

\section{Analisis Deskriptif}

Penulis melakukan analisis deskriptif untuk mendeskripsikan atau menggambarkan statistik data yang telah terkumpul. Pada variabel job stress nilai mean yang didapatkan 19,0 (SD=7,20; Min=7;Max=37) artinya partisipan memiliki tingkat stres kerja yang sedang. Pada variabel job demand didapatkan nilai mean 69,1 (SD=11,2; Min=44; Max=103) artinya partisipan memiliki job demand yang sedang. Terutama pada dimensi work overload tingkat beban kerja berlebih yang mereka memiliki masuk pada tingkat tinggi. Pada variabel perceived organizational support didapatkan nilai mean 29,6 (SD=6,19; Min=15; Max=42) artinya partisipan memiliki tingkat dukungan organisasi yang tinggi. 


\section{Analisis Regresi}

Pada penelitian ini penulis menggunakan analisis regresi linear dan multiple regression untuk melihat pengaruh work overload dengan stres kerja, perceived organizational support dengan job stress, dan pengaruh work overload dan perceived organizational support dengan job stress didapatkan hasil dari multiple regression $\left(F(2,90)=11,9 ; p=<0,001 ; R^{2}=0,21\right)$ varians data dari work overload dan perceived organizational support dapat menjelaskan $21 \%$ dari varians job stress. Dapat disimpulkan bahwa work overload dan perceived organizational support secara simultan memiliki pengaruh yang signifikan terhadap job stress.

Pada model koefisien regresi linear didapatkan work overload $(B=0,58 ; 95 \%$ CI $[-0,23 ; 0,19]$; $S E=0,10$; $t=-0,16 ; p=<0,001$ ) berkorelasi positif dalam menjelaskan job stress. Kemudian perceived organizational support $(B=-0,16 ; 95 \%$ CI $[-0,40 ; 0,07] ; S E=0,12 ; t=-1,38 ; p=0,17)$ berkorelasi negatif dalam menjelaskan job stress. Maka dapat disimpulkan bahwa work overload dengan job stress berkorelasi positif dan memiliki pengaruh yang signifikan, sedangkan pada perceived organizational support dengan job stress memiliki korelasi negatif, tetapi tidak memiliki pengaruh yang signifikan.

Penulis melakukan analisis tambahan untuk mengetahui pengaruh masing-masing dimensi dari variabel job demand terhadap job stress. Dapat diketahui dimensi emotional demand $(B=0,51 ; 95 \%$ CI $[0,24 ; 0,77] ; S E=0,13 ; t=-3,80 ; p=<0,001$ ) yang memiliki korelasi positif dan berpengaruh signifikan pada job stress. Selanjutnya pada dimensi cognitive demand didapatkan $(B=0,53 ; 95 \% \mathrm{CI}[0,23 ; 0,83]$; $S E=0,15 ; t=-3,54 ; p=<0,001$ ) yang berkorelasi positif dan memiliki pengaruh signifikan pada job stress. Jadi, Variabel job demand memiliki korelasi positif yang memiliki pengaruh signifikan dengan job stress. Pada varians data yang didapatkan untuk emotional demand 13,7\%, cognitive demand 12,1\%, work overload $18,4 \%$ yang artinya varians data yang mempengaruhi job stress paling banyak pada dimensi work overload.

\section{I S K U S I}

Penelitian ini bertujuan untuk mengetahui adakah pengaruh work overload dan perceived organizational support dengan job stress pada pegawai Bank Mandiri Unit Marketing Consumer Loans Area Surabaya yang terdapat tiga cabang di Surabaya. Pada uji regresi linear hasil yang didapatkan ada pengaruh yang signifikan work overload dengan job stress. Hal ini dibuktikan oleh hasil signifikansi uji analisis regresi pada model 1 nilai koefisien regresi $\left(\mathrm{R}^{2}\right)$ sebesar 0,184 . Nilai tersebut menunjukan bahwa work overload overlap sebanyak $18,4 \%$ dengan variabel job stress. Artinya tingkat work overload yang dimiliki pegawai dapat memprediksi dan menggambarkan job stress hanya sebesar 18,4\%. Jadi, work overload memiliki pengaruh bermakna atau signifikan terhadap job stres.

Hasil penelitian tersebut sesuai seperti penelitian milik Boaz (2017) membahas hal yang sama mengenai pengaruh work overload dengan job stress pada pegawai memiliki pengaruh 23,6\% terhadap job stress (Sahaduta \& Noermijati, 2017). Sedangkan hasil yang didapat oleh peneliti yaitu memiliki pengaruh yang signifikan dan memiliki pengaruh sebesar yaitu 18,4\% dengan nilai signifikan p kurang dari $<0,001$. Pada hasil penelitian ini pengaruh yang paling dominan dari variabel job demand yaitu work overload terhadap stres kerja dengan pengaruh sebesar 18,4\%. Pada penelitian ini pengaruh yang paling dominan dari variabel job demand yaitu work overload terhadap stres kerja dengan pengaruh sebesar 18,4\%. Sedangkan emotional demand 12,7 dan cognitive demand 13,7. Hal tersebut membuktikan bahwa Job demand dapat menjadi salah satu prediktor yang mempengaruhi stres kerja. 
Hal tersebut membuktikan bahwa job demand dapat menjadi salah satu prediktor yang mempengaruhi stres kerja.

Work overload menjadi salah satu penyebab pegawai merasa dibawah tekanan dimana pekerjaan menuntut mereka untuk bekerja berlebihan sehingga berakhir pada stres kerja (Demerouti dkk., 2001) . Setiap orang pernah mengalami beban kerja yang terlalu berat pada suatu waktu. Beban kerja berlebihan adalah kondisi yang terjadi bila lingkungan memberikan tuntutan melebihi kemampuan individu (Gibson, Ivancevich, Donnelly, 2011). Risiko langsung Covid-19 ini berdampak pada pekerjaan mereka yang mengalami tingkat kesusahan karena adanya pandemi ini yang mempengaruhi cara manusia melangsungkan kehidupannya (Lanciano dkk., 2020). Terdapat beberapa pekerjaan yang dapat diselesaikan dengan cepat menjadi terhambat karena keputusan yang harus diambil oleh pihak lain, hal ini membuat pekerjaan terhambat dan memakan waktu lama mengakibatkan pekerjaan lain tertunda dan bertambah lagi. Hal ini membuat pegawai menjadi stres merasa mereka tidak memiliki kendali atas jadwal, interaksi, dan manajemen waktu (Faaroek, 2020).

Menurut Brooks dkk, (2020) Menjelaskan pekerjaan yang biasa dilakukan menjadi bertambah untuk melindungi diri kita sendiri yang menyebabkan efek psikologis negatif termasuk gangguan emosional, depresi, stres, suasana hati rendah, dan lain-lain (Handayani dkk., 2020). Pekerjaan yang bertambah menimbulkan beban untuk mereka dimana mereka harus bekerja untuk mencapai target dan sekaligus juga menjaga kesehatan mereka. Hal tersebut sesuai dengan yang terjadi di pegawai Bank Mandiri consumer loan area Surabaya yang dimana pegawai selama bekerja mengalami banyak hambatan, pengerjaan tugas yang waktunya sedikit, dan beban kerja berlebihan yang tinggi yang mempengaruhi stres kerja mereka. Work overload yang diterima meliputi beban tanggung jawab, banyaknya tugas yang diterima, dan waktu pengerjaan tugas yang harus diselesaikan.

Peneliti juga meneliti pengaruh perceived organizational support dengan job stress nilai koefisien regresi $\left(\mathrm{R}^{2}\right)$ menunjukan bahwa varians perceived organizational support overlap sebanyak 2,04\% dengan variabel job stress sisanya dipengaruhi oleh faktor lain yang tidak diteliti oleh peneliti. Nilai $\mathrm{p}$ yang dihasilkan adalah 0,172 sehingga $\mathrm{H}_{2}$ ditolak. Dengan demikian perceived organizational support tidak memiliki pengaruh yang bermakna dengan job stress, serta memiliki pengaruh negatif pada job stress. Pada acuan yang digunakan peneliti bahwa adanya pengaruh yang signifikan antara perceived organizational support dengan job stress serta arahnya yang negatif. Seperti pada penelitian yang dilakukan Linda Futriani (2020) hasil penelitian menunjukan arah yang negatif dan signifikan terhadap stres kerja. Hasil penelitian tersebut membuktikan bahwa perceived organizational support yang tinggi dapat mengurangi tingkat stres kerja pada pegawai (Futriani, 2020).

Pada kenyataanya hasil tetapi memiliki arah yang negatif. Hasil tersebut sesuai pada penelitian yang dilakukan Bakker (2017) analisis regresi yang menunjukan bahwa POS tidak memiliki pengaruh langsung yang signifikan dengan stres kerja, Jadi POS tidak sesuai dengan teori sebelumnya yang menyatakan bahwa POS dapat memberikan efek positif dan menurunkan stres kerja menjadi lebih kecil (Bakker, 2017). Pada penelitian yang dilakukan Kristie tidak menurunkan pengaruh langsung antara POS dengan Stres kerja. Ada kemungkinan pegawai tidak menganggap dukungan dari organisasi sebagai sesuatu yang positif. Terutama pegawai yang awalnya sudah berperilaku sinis tidak mengalami dukungan dari organisasi untuk membantu dan bahwa pegawai tersebut bereaksi negatif terhadap dukungan karena tidak tahu apa maksud dari organisasi tersebut (Byrne \& Hochwater, 2008). Menurut Mujiasih (2015) pegawai yang tidak mendapatkan perhatian dan dihargai keberadaanya akan memberikan perasaan ketidaknyamanan pada pegawai, timbulnya ketidakpuasan, dan tidak adanya keterikatan pada perusahaan yang berdampak pada kinerja pegawai (Mujiasih, 2015). Hasil penelitian juga seperti pada penelitian yang dilakukan lain pada pegawai Bank dimana kurangnya dukungan 
organisasi yang diterima pegawai seperti pengembangan karir yang tidak sesuai dan suasana pekerjaan yang kurang nyaman menyebabkan rendahnya keinginan pegawai untuk dapat bekerja secara maksimal (Muliana, Hafasnuddin, 2015).

Pengaruhnya pada perceived organizational support dengan stres kerja di masa pandemi ini sangatlah penting. Strategi kebijakan dilakukan oleh perusahaan agar pegawai dapat bekerja secara optimal meskipun di kondisi pandemi. Perhatian dalam masa pandemi diperluas lagi tidak hanya fokus pada hal yang dikerjakan dan juga pelanggan, tetapi memberi perhatian kesehatan dan keselamatan pegawainya adalah salah satu dukungan organisasi untuk pegawai. Hal ini dilakukan untuk membangun kesehatan mental dan emosional pegawai pada organisasi walaupun kerja yang dilakukan di masa pandemi (Rosdiana, 2020). Melihat dari hasil penelitian dimana perceived organizational support tidak mempengaruhi secara signifikan pada stres kerja mereka dapat disimpulkan pegawai Bank Mandiri consumer loan area Surabaya dapat melindungi dirinya sendiri dan memahami betul menghindari Covid-19 meskipun tanpa bantuan dukungan organisasi. Perceived organizational support yang didapatkan pegawai tidak menjadi sumber turunnya stres kerja, perceived organizational support lebih mengarah penciptaan emosional seperti komitmen terhadap organisasi, tetapi tidak menurunkan stres kerja mereka (Rhoades \& Eisenberger, 2002).

Seperti pada penelitian yang dilakukan Julita dan Andriani (2017) dimana pegawai menunjukan dirinya tidak dihargai dan diperhatikan seta rekan kerja yang kurang peduli dengan lingkungan kerja sehingga hal tersebut membuat pegawai tidak termotivasi dalam bekerja yang bisa menimbulkan perilaku negatif kepada perusahaan seperti tidak peduli terhadap pekerjaan dan berdampak pada penurunan performa dalam bekerja. Akan lebih baik jika organisasi memberikan dukungan yang dapat mengurangi stres kerja mereka dikondisi pandemi ini seperti menurut Eisnberger, dkk (2002) perceived organizational support dapat mengurangi tekanan psikologis sehingga pegawai akan mengenali pekerjaanya secara positif dan pegawai akan lebih terikat dengan organisasi (Rhoades \& Eisenberger, 2002). Jadi, perceived organizational support menciptakan perasaan kewajiban untuk membantu organisasi dan bukan perasaan.

Selanjutnya hasil yang didapatkan adalah work overload dan perceived organziational support. Nilai $p<$ 0,001 sehingga hasilnya diperoleh signifikan dan dapat memprediksi data pengaruh kedua variabel $21 \%$ terhadap job stress. Oleh karena itu, hasil yang didapatkan work overload dan perceived organizational support dengan job stress memiliki pengaruh yang signifikan. Dengan adanya work overload membuat perceived organizational support memiliki hubungan bermakna dengan job stress karena dengan memberikan dukungan, pegawai mampu mengatasi tuntutan pekerjaan yang tinggi. POS juga dilihat sebagai jaminan bagi pegawai bahwa bantuan akan tersedia dari perusahaan ketika diperlukan untuk melaksanakan pekerjaan mereka secara efektif dan juga untuk mengatasi stres di tempat kerja (Rhoades \& Eisenberger, 2002). Handayani, dkk (2020) menemukan penyebab stres selama pandemi ini karena beban kerja, hubungan rekan kerja, ketidakjelasan peran, perubahan organisasi, kepuasan kerja, dan kesejahteraan psikologis pekerja yang kurang.

Pada hasil kategorisasi yang didapatkan untuk stres kerja pegawai didapatkan paling banyak pada kategorisasi sedang. Menurut Cullen, dkk (1985) stres kerja adalah kondisi ketidaknyamanan psikologis akibat paparan stressor yang diterima. Pegawai Bank Mandiri mengalami tingkat stres kerja sedang yang berarti stressor yang membuat ketidaknyamanan tersebut tidak begitu tinggi atau bisa dikontrol oleh mereka (Cullen dkk., 1985). Sedangkan kategorisasi work overload yang diterima pegawai Bank Mandiri consumer loan itu tinggi. Setiap pegawai mengalami beban kerja yang terlalu berat pada suatu waktu karena lingkungan memberikan tuntutan berlebih. Pegawai bank Mandiri consumer loan menerima beban kerja berlebih dikarenakan tuntutan dari lingkungan (Gibson, Ivancevich, Donnelly, 2011). Beban 
kerja berlebihan ini bisa meliputi waktu pengerjaan yang cepat, tanggung jawab, tugas yang melebihi kemampuan individu di masa pandemi saat ini. Sedangkan kategorisasi dari perceived organizational support didapatkan hasilnya tinggi, dilihat sebagai jaminan bagi pegawai bahwa bantuan akan tersedia dari perusahaan ketika diperlukan untuk melaksanakan pekerjaan mereka secara efektif dan juga untuk mengatasi stres kerja (Rhoades \& Eisenberger, 2002).

\section{S I M P U L A N}

Berdasarkan pada penelitian ini dapat ditarik kesimpulan bahwa work overload memiliki pengaruh signifikan dengan job stress di kondisi pandemi pada pegawai bank di Surabaya. Selain itu hasil penelitian juga menunjukkan bahwa perceived organizational support tidak memiliki pengaruh signifikan dengan job stress di masa pandemi pada pegawai Bank di Surabaya. Sert work overload dan perceived organizational support dengan job stress memiliki pengaruh yang signifikan di masa pandemi pada pegawai Bank di Surabaya.

Saran yang ditunjukan bagi peneliti selanjutnya adalah pengambilan data dilapangan bisa dipertimbangkan untuk mengambil sampel yang lebih banyak dari penelitian ini seperti menambah unit lain agar hasilnya dapat digeneralisasikan. Penelitian yang dilakukan dapat memilih kantor cabang lain atau yang berbeda dengan yang sudah diteliti agar dapat memberikan hasil penelitian yang jauh lebih representatif hasilnya. Saran selanjutnya bagi pegawai bank di Surabaya Bagi pegawai mengelola stres kerja yang mereka miliki dengan mereduksi work overload yang dirasakan oleh pegawai seperti membagi tugas dengan tidak berlebih, memberikan waktu pengerjaan jangan terlalu singkat. Menciptakan lingkungan kerja yang nyaman dan terlindungi oleh pegawai sendiri. Pada kondisi pandemi saat ini siapa lagi yang bisa menjaga kondisi tubuh kalau bukan dari kita sendiri karena perusahaan tidak tahu kapan individu itu akan terkena virus.

Bagi organisasi memperhatikan pegawainya dengan pelatihan manajemen stres kerja untuk pegawai Bank. Pelatihan pegawai pada saat masa pandemi dapat menyelesaikan permasalahan pengembangan SDM. Selain itu bagi pemimpinan untuk memberikan feedback dan motivasi yang membangun agar anggota lebih semangat dalam bekerja dan meredam stres kerja yang dirasakan.

\section{U C A P A N T E R I MAKASIH}

Penulis berterimakasih kepada Allah SWT, keluarga, orang-orang terdekat penulis, partisipan yang membantu penulis dalam pengisian kuesioner penelitian, dan pihak-pihak lain yang membantu dalam penyelesaian penelitian ini.

\section{DEKLARASI POTENSI TERJADINYA KONFLIK KEPENTINGAN}

Adinda Reza Maulina dan Dimas Aryo Wicaksono tidak bekerja, menjadi konsultan, memiliki saham, atau menerima dana dari perusahaan atau organisasi maupun yang mungkin akan mengambil untuk dari diterbitkannya naskah ini.

\section{PUSTAKA ACUAN}

Alifah, E. W. (2020). Pengaruh Stres Kerja, dan Beban Kerja, terhadap Kinerja Karyawan. Journal of 
Management and Bussines (JOMB), 1, 83-98. https://doi.org/10.31539/jomb.v2i1.1215

Arbar, T. F. (2021). Jangan Terkejut! Banyak Karyawan Sakit Mental karena Pandemi. https://www.cnbcindonesia.com/lifestyle/20210215121049-33-223352/jangan-terkejutbanyak-karyawan-sakit-mental-karena-pandemi

Arsyad, F. (2021). Prosiding. Jurnal Prosiding Politeknik Kesejahteraan Sosial (Polteksos) Bandung, 160169.

Bakker, A. B., Demerouti, E., Taris, T. W., Schaufeli, W. B., \& Schreurs, P. J. G. (2003). A Multigroup Analysis of the Job Demands-Resources Model in Four Home Care Organizations. International Journal of Stress Management, 10(1), 16-38. https://doi.org/10.1037/1072-5245.10.1.16

Bakker, K. (2017). Role Overload and Job Stress : The Role of Perceived Organizational Support. June, 123.

Byrne, Z. S., \& Hochwater, W. A. (2008). Perceived organizational support and performance relationships across levels of organizational cynicism. Journal of Managerial Psychology, 23(1), 54-72. https://doi.org/10.1108/02683940810849666

Chandra, D. (2018). Konflik Kerja dan Stres Kerja Terhadap Kinerja Karyawan pada PT . Bank Tabungan Negara Tbk. ReserachGate, September. https://www.researchgate.net/publication

Cullen, F. T., Link, B. G., Wolfe, N. T., \& Frank, J. (1985). The social dimensions of correctional officer stress. Justice Quarterly, 2(4), 505-533. https://doi.org/10.1080/07418828500088711

De Jonge, J., Van Breukelen, G. J. P., Landeweerd, J. A., \& Nijhuis, F. J. N. (1999). Comparing group and individual level assessments of job characteristics in testing the job Demand-Control Model: A multilevel Human Relations, https://doi.org/10.1023/A:1016924517061

Delfianti, W. (2019). PENGARUH STRES KERJA TERHADAP KINERJA KARYAWAN PADA PT BANK MANDIRI (PERSERO) Tbk AREA MEDAN IMAM BONJOL. In Jurnal Akuntansi. Politeknik Negeri Medan.

Demerouti, E., Nachreiner, F., Bakker, A. B., \& Schaufeli, W. B. (2001). The job demands-resources model of burnout. Journal of Applied Psychology, 86(3), 499-512. https://doi.org/10.1037/00219010.86.3.499

Eisenberger, R., Huntington, R., Hutchison, S., \& Sowa, D. (1986). Perceived Organizational Support. In Journal of Applied Psychology (Vol. 71, Issue 3, pp. 500-507). https://doi.org/10.1037/00219010.71.3.500

Faaroek, A. (2020). Pengaruh Job Demand Terhadap Turnover Intention Melalui Burnout Pada Karyawan Work From Home. 17(September).

Futriani, L. (2020). Pengaruh Job Demand, Perceived Organizational Support Terhadap Work Stress Dan Implikasinya Pada Employee Performance Di Balai Diklat Industri Surabaya [Universitas Airlangga].

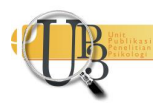


http://repository.unair.ac.id/98345/

Gibson, Ivancevich, Donnelly, K. (2011). Organizations: Behavior, Structure, Processes (P. Ducham (ed.); Fourteenth). McGraw-Hill Irwin.

Handayani, R. T., Kuntari, S., Darmayanti, A. T., Widiyanto, A., \& Atmojo, J. T. (2020). Faktor Penyebab Stres Pada Tenaga Kesehatan Dan Masyarakat Saat Pandemi Covid-19. Jurnal Keperawatan Jiwa, 8(3), 353.

ILO. (2014). Safety and Health at Work: A Vision for Sustainable Prevention.

Julita, S., \& Andriani, I. (2017). Santi Julita, Iin Andriani. 16(1), 40-53.

Karunia, A. M. (2020). Survei PPM Manajemen: 80 Persen Pekerja Mengalami gejala Stres Karena Khawatir Kesehatan. https://money.kompas.com/read/2020/06/05/133207026/survei-ppmmanajemen-80-persen-pekerja-mengalami-gejala-stres-karena-khawatir.

Lanciano, T., Graziano, G., Curci, A., Costadura, S., \& Monaco, A. (2020). Risk Perceptions and Psychological Effects During the Italian COVID-19 Emergency. Frontiers in Psychology, 11(September). https://doi.org/10.3389/fpsyg.2020.580053

Laschinger, P. (2006). The effect of structural empowerment and perceived organizational support on middle level nurse managers ' role satisfaction. Journal of Nursing Management, 14(July 2005), 1322.

Luthans, F. (2009). Organizational Behavior. In McGraw-Hill Irwin. https://doi.org/10.5005/jp/books/10358_23

Malik, N. (2011). A study on occupational stress experienced by private and public banks employees in Quetta City. African Journal of Business Management, 5(8), 3063-3070. https://doi.org/10.5897/AJBM10.199

Maulidyah, I. A. (2017). Pengaruh stres kerja terhadap kinerja karyawan back office dengan motivasi sebagai variabel intervening pada pt. bank tabungan negara (persero), tbk kantor cabang surabaya. Jurnal Ilmu Manajemen Volume, 5(3).

Mujiasih, E. (2015). Hubungan Antara Persepsi Dukungan Organisasi (Perceived Organizational Support) Dengan Keterikatan Karyawan. Jurnal Psikologi Undip, 14(1), 40-51. https://doi.org/10.14710/jpu.14.1.40-51

Muliana, Hafasnuddin, M. I. (2015). Pengaruh budaya organisasi, pengembangan karir dan kepuasan kerja terhadap kinerja karyawan serta dampaknya pada kinerja bank bri cabang bireuen. 4(2), 202210.

Neuman, W. L. (2014). Social Research Methods: Qualitative and Quantitative Approaches. In Teaching Sociology (Seven Edit, Vol. 30, Issue 3). Pearson Education Limited. https://doi.org/10.2307/3211488 
Parker, D. (1983). Theories of team cognition: Cross-disciplinary perspectives. Theories of Team Cognition: Cross-Disciplinary Perspectives, 32, 160-177. https://doi.org/10.4324/9780203813140

Pratiwi, Y. (2020). Pengaruh Konflik Peran Ganda, Stress Kerja dan Beban Kerja Terhadap Kinerja Karyawan Dengan Lingkungan Kerja Sebagai Variabel Moderasi. Institut Agama Islam Negeri Salatiga, 1-120.

Puci, M. V., Nosari, G., Loi, F., Puci, G. V., Montomoli, C., \& Ferraro, O. E. (2020). Risk Perception and Worries among Health Care Workers in the COVID-19 Pandemic: Findings from an Italian Survey. Healthcare, 8(4), 535. https://doi.org/10.3390/healthcare8040535

Putri, K. R. (2020). Mengelola Stres Pegawai di Tengah Pandemi Covid-19. Djkn.Kemenkeu.Go.Id. https://www.djkn.kemenkeu.go.id/artikel/baca/13486/Mengelola-Stres-Pegawai-di-TengahPandemi-Covid-19.html

Rakhmawati, V. E., \& Syarifah, D. (2017). Jurnal Psikologi Industri dan Organisasi LEMBAGA PEMASYARAKATAN KLAS I SURABAYA. Jurnal Psikologi Industri Dan Organisasi, 6(4), 78-92.

Rhoades, L., \& Eisenberger, R. (2002). Perceived organizational support: A review of the literature. Journal of Applied Psychology, 87(4), 698-714. https://doi.org/10.1037/0021-9010.87.4.698

Rosdiana, Y. (2020). Dampak Covid-19 Terhadap Budaya Organisasi Perusahaan. https://www.ayosemarang.com/read/2020/06/15/58742/dampak-covid-19-terhadap-budayaorganisasi-perusahaan

Sahaduta, B. Y., \& Noermijati. (2017). PENGARUH KESELAMATAN DAN KESEHATAN KERJA (K3) DAN WORK OVERLOAD TERHADAP JOB STRESS PADA KARYAWAN PT BAHARI UTAMA KARYA. Jurnal Ekonomi Dan Bisnis.

Setiawan, M. (2018). Pengaruh Stres Kerja Terhadap Kepuasan Kerja dan Kinerja Karyawan PT. Bank Negara Indonesia (Persero) TBK Cabang Universitas Brawijaya. Jurnal Ilmiah Mahasiswa, 7(1), 11.

Singh, G., Singh, A., Zaidi, S. Z. H., \& Sharma, S. (2020). a Study on Mental Health and Well-Being of Individuals Amid Covid-19 Pandemic Lockdown. IX(V), 952-963.

Siu, H., Spence Laschinger, H. K., \& Finegan, J. (2008). Nursing professional practice environments: Setting the stage for constructive conflict resolution and work effectiveness. Journal of Nursing Administration, 38(5), 250-257. https://doi.org/10.1097/01.NNA.0000312772.04234.1f

Sudrajat, A. (2019). Pengaruh Beban Kerja dan Dukungan Supervisor terhadap Stress Kerja (Studi pada karyawan PT. SMI/Seluler Media Infotama, Kota Bontang, Kalimantan Timur). Jurnal Administrasi Bisnis (JAB), 67(1), 8-14. http://administrasibisnis.studentjournal.ub.ac.id/index.php/jab/article/view/2783/3171

Susetyo, R. I., \& Ratnaningsih, I. Z. (2016). Dan Stres Kerja Pada Karyawan Bagian Produksi. 5(1), 55-59. Syahrizal Sidik. (2020). Bank Mandiri: UMKM Paling Banyak Ajukan Keringanan Kredit. CNBC Indonesia. https://www.cnbcindonesia.com/market/20200402120039-17-149333/bank-mandiri-umkm-

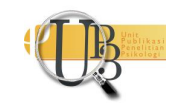


paling-banyak-ajukan-keringanan-kredit

UURI. (1998). Undang-Undang Republik Indonesia No. 10 Tahun 1998 Tentang Perbankan. Lembaran Negara Republik Indonesia, 182. http://www.bphn.go.id/data/documents/98uu010.pdf

Wulandari, B. (2021). PENGARUH PERCEIVED ORGANIZATIONAL SUPPORT DAN EMPLOYEE ENGAGEMENT TERHADAP KESIAPAN BERUBAH KARYAWAN BANK X CABANG MEDAN TESIS. Universitas Sumatera Utara. 